
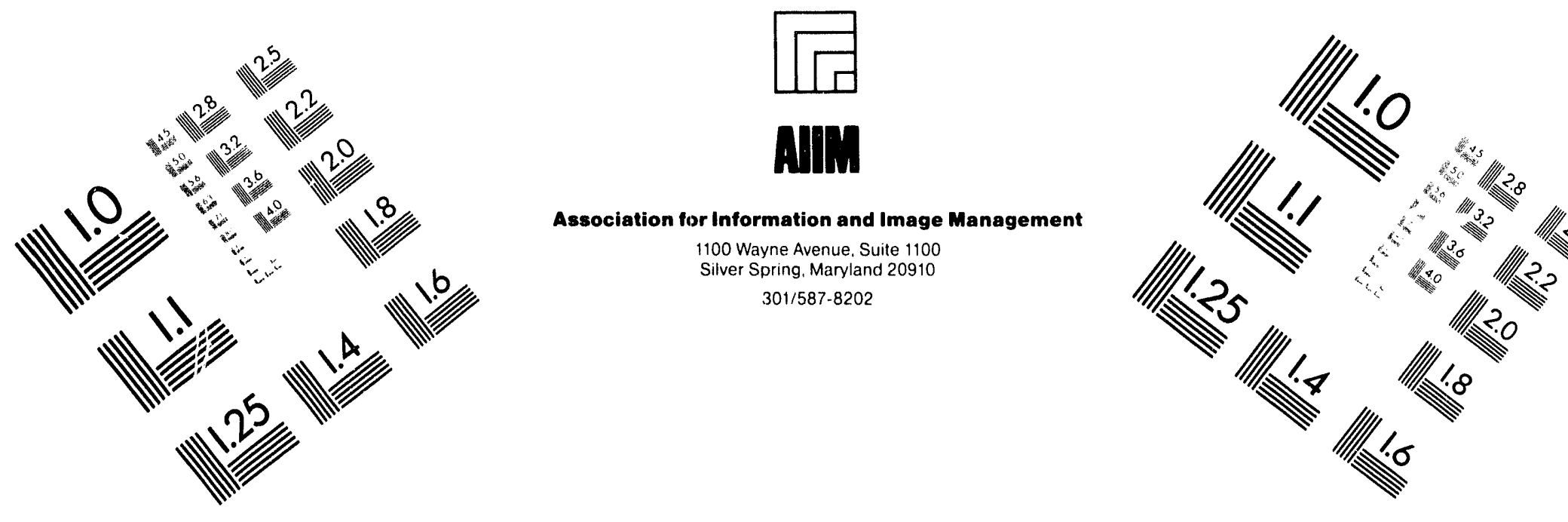

Centimeter

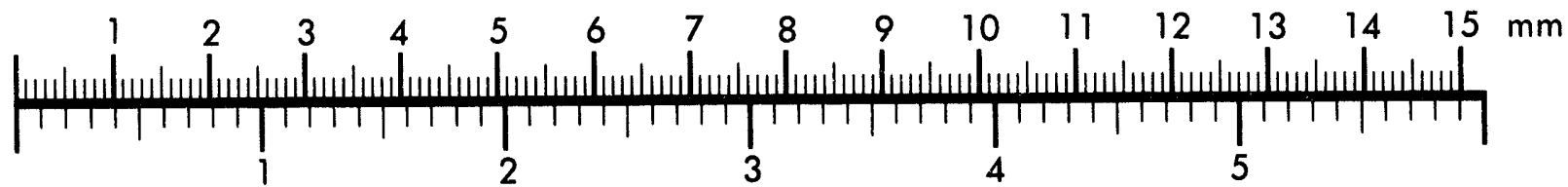

Inches
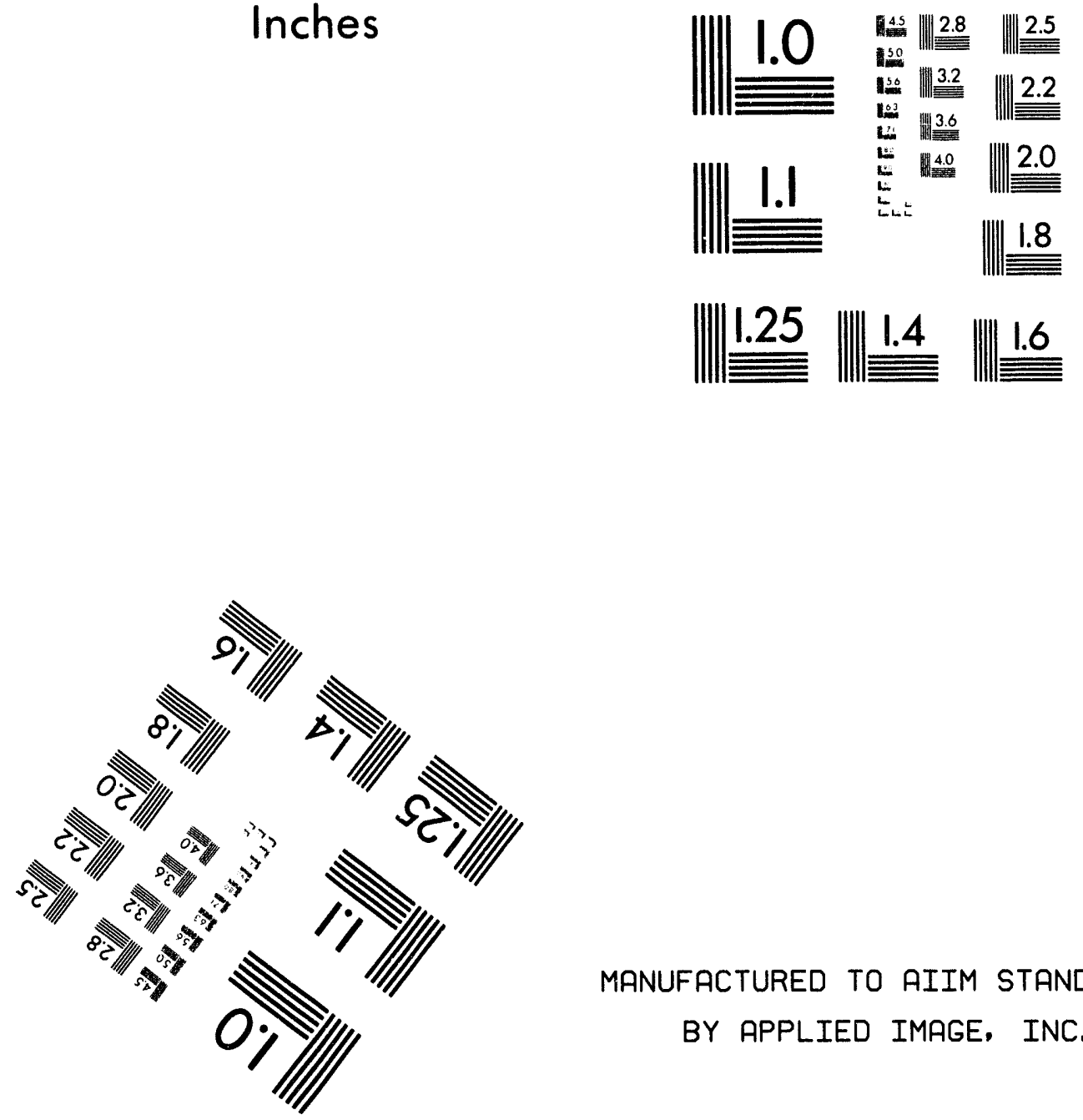

MANUFACTURED TO AIIM STANDARDS

BY APPLIED IMAGE, INC.

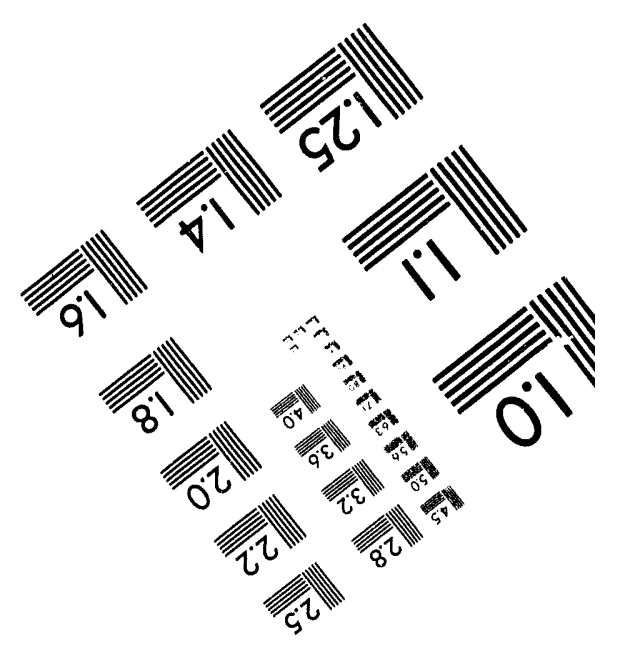



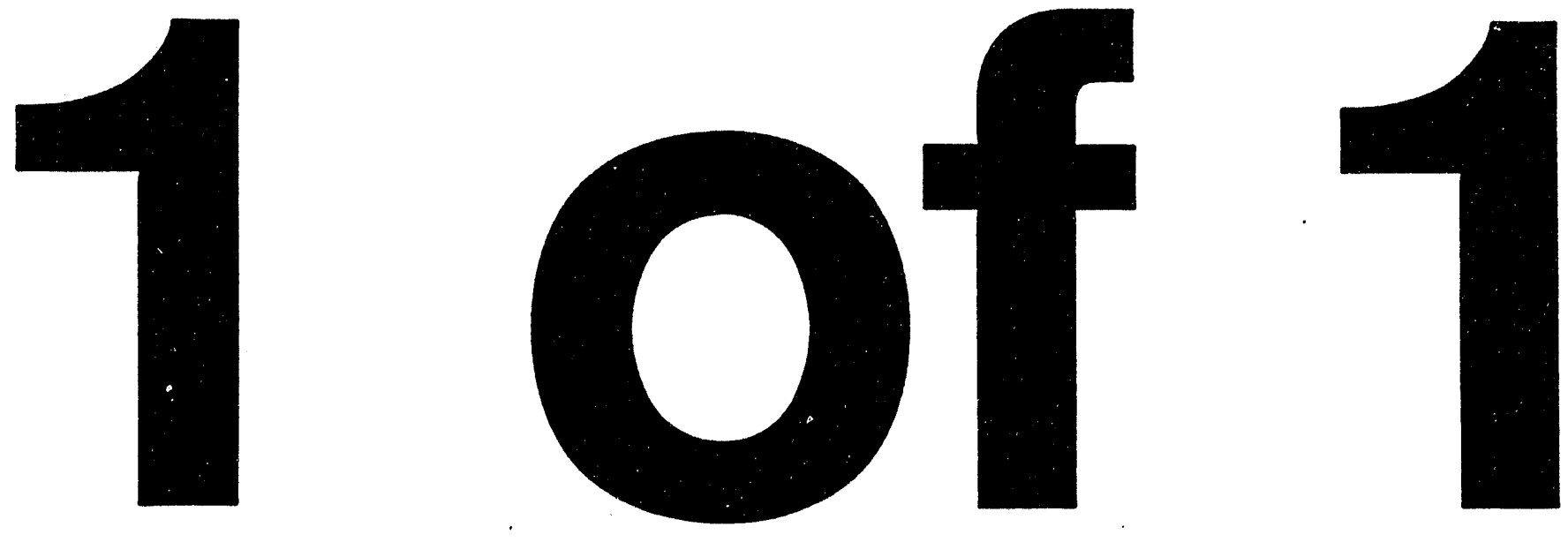


\title{
Results of TSP Metals Monitoring at McMurdo Station, Antarctica
}

\author{
R. M. Lugar
}

Published April 1994

\section{Idaho National Engineering Laboratory EG\&G Idaho, Inc. Idaho Falls, Idaho 83415}

\footnotetext{
Interagency Agreement No. DPP-9102787
}

with the

U.S. Department of Energy Idaho Operations Office Idaho Falls, Idaho 83402 and

Dr. Jane Dionne, Program Manager, Polar Coordinated Sclence Projects National Science Foundation Office of Polar Programs Arlington, VA 22230

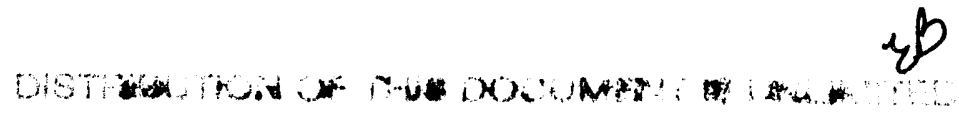




\begin{abstract}
This report presents the results of ambient air monitoring of metals in total suspended particulate (TSP) matter performed during the 1992-1993 austral summer at McMurdo Station, Antarctica. Seven samples of TSP were collected from three different locations and analyzed for arsenic, beryllium, cadmium, chromium, lead, nickel, and mercury. Critical-flow high-volume air samplers with a sample flow rate of approximately $1.1 \mathrm{~m}^{3} /$ minute were used to collect the particulate matter on quartz fiber filters for subsequent laboratory analysis. Sampling site selection, sampling procedures, and quality assurance procedures used were consistent with U.S. Environmental Protection Agency guidance for local ambient air quality networks. The data indicate that McMurdo operations have a measurable impact on the qualitative toxic metals composition of suspended particulate matter in the ambient air; however a definitive quantitative impact could not be concluded. The levels measured are well below the U.S. National Ambient Air Quality Standards and American Conference of Governmental Industrial Hygienists worker exposure levels. Lead was the most prevalent of the seven toxic metals and was detected in all samples at concentrations ranging from $1.4 \mathrm{ng} / \mathrm{m}^{3}$ to $38 \mathrm{ng} / \mathrm{m}^{3}$. Data on the concentration of eleven other metal species are presented. Most notable was the relatively high abundance of titanium and copper, which were detectable at levels up to $2,100 \mathrm{ng} / \mathrm{m}^{3}$ and $230 \mathrm{ng} / \mathrm{m}^{3}$, respectively.
\end{abstract}




\section{CONTENTS}

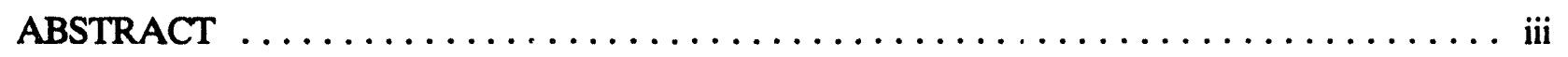

INTRODUCTION $\ldots \ldots \ldots \ldots \ldots \ldots \ldots \ldots \ldots \ldots \ldots \ldots \ldots \ldots \ldots \ldots \ldots$

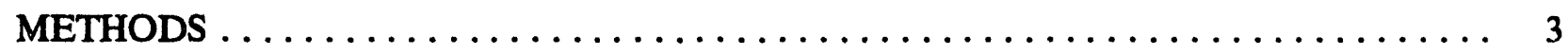

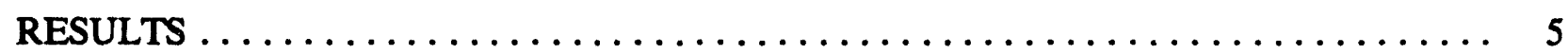

REFERENCES $\ldots \ldots \ldots \ldots \ldots \ldots \ldots \ldots \ldots \ldots \ldots \ldots \ldots \ldots \ldots \ldots \ldots$

FIGURES

1. Map of ambient air monitoring stations at McMurdo $\ldots \ldots \ldots \ldots \ldots \ldots$

2. TSP toxic metals concentration at Central McMurdo $\ldots \ldots \ldots \ldots \ldots \ldots \ldots$

3. TSP toxic metals concentration at Hut Point $\ldots \ldots \ldots \ldots \ldots \ldots \ldots \ldots$

4. TSP toxic metals concentration at 8 -Site $\ldots \ldots \ldots \ldots \ldots \ldots \ldots \ldots$

5. Ratio of toxic metals to TSP at Central McMurdo $\ldots \ldots \ldots \ldots \ldots \ldots \ldots \ldots$

6. Ratio of toxic metals to TSP at Hut Point $\ldots \ldots \ldots \ldots \ldots \ldots \ldots \ldots \ldots$

7. Ratio of toxic metals to TSP at 8 -Site $\ldots \ldots \ldots \ldots \ldots \ldots \ldots \ldots \ldots \ldots$

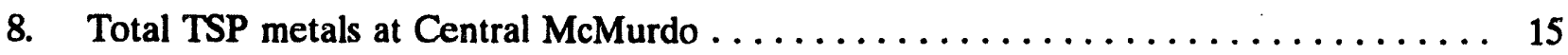

9. Total TSP metals at Hut Point $\ldots \ldots \ldots \ldots \ldots \ldots \ldots \ldots \ldots \ldots \ldots \ldots \ldots \ldots$

10. Total TSP metals at 8 -Site $\ldots \ldots \ldots \ldots \ldots \ldots \ldots \ldots \ldots \ldots \ldots \ldots \ldots \ldots$

\section{TABLES}

1. Comparison of sources of products of combustion at McMurdo Station $\ldots \ldots \ldots \ldots$

2. Estimated annual air pollutant emissions at McMurdo Station $\ldots \ldots \ldots \ldots$

3. TSP ambient air cor_entration data summary for McMurdo Station, austral summer

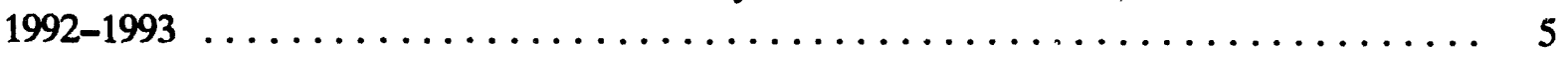

4. Summary of metals composition of $\mathrm{TSP}$ filters $\ldots \ldots \ldots \ldots \ldots \ldots \ldots \ldots$ 


\section{Results of TSP Metals Monitoring at McMurdo Station, Antarctica}

\section{INTRODUCTION}

McMurdo Station $\left(77^{\circ} 51^{\prime}\right.$ South $166^{\circ} 40^{\prime}$ East) is the largest human community in Antarctica. It is a coastal station constructed on low ash and volcanic hills at the southern tip of Ross Island. McMurdo serves as the primary logistics and staging facility for airborne resupply of inland research stations and supports a wide variety of scientific research sponsored by the United States National Science Foundation's Antarctic Program. The austral winter (March-September) population in 1992 was 257, and the austral summer (October-February) population exceeded 1,100. The station consists of over 100 structures, and numerous equipment laydown and storage areas. A skiway airport located approximately $16 \mathrm{~km}$ from McMurdo and sea-ice runway approximately $5 \mathrm{~km}$ away serve fixed-wing aircraft for flights to the Antarctica mainland, as well as flights to and from New Zealand. Emissions of atmospheric pollutants at or near McMurdo result from a variety of sources, including boilers, furnaces, space heaters, electric generators, motor vehicle engines, incinerator, fugitive dust, petroleum storage tank vapors, aircraft operations, and ships. The major fixed-air emission source is believed to be the electric generation plant. Tables 1 and 2 summarize the major source categories and estimated air pollutant/products of combustion emissions at McMurdo.

A report on the National Science Foundation (NSF) implementation of a strategy to comply with environmental law in Antarctica (NSF 1989) established the need to assess the environmental impact of air emissions at McMurdo Station and other U.S. Stations. In addition, the recent Protocol on Environmental Protection to the Antarctic Treaty (NSF 1991) and implementation of interim solid waste incineration during the 1992-1993 austral summer season at McMurdo further underlined the need to implement an ambient air monitoring network. Waste incineration at McMurdo ceased on March 22, 1993. In 1992, an ambient air monitoring plan for Mcmurdo was prepared that established the objectives of the monitoring effort. These objectives are to (a) determine the highest concentrations of pollutants expected to occur in the area covered by the network, (b) determine representative concentrations of selected air pollutants in areas of high population density, (c) determine the impact on ambient pollution levels of significant sources or source categories, and (d) determine background levels of selected air pollutants (Lugar 1992).

The objectives and performance criteria established for the monitoring network were consistent with the intent of U.S. Environmental Protection Agency (EPA) State and Local Air Monitoring Stations objectives and network design (see Appendix D of 40 CFR 58). Quality assurance and quality control aspects of the particulate monitoring effort were generally consistent with EPA sampling procedures (see Appendix B and Appendix J of 40 CFR 50), and the EPA Quality Assurance Handbook (EPA 1977). Colocation of particulate samplers was not feasible during this initial baseline effort due to the limited number of samplers and the relatively short summer season. A variety of air pollutants, including many for which the EPA has established National Ambient Air Quality Standards, were selected for monitoring. Particulate matter with a diameter less than or equal to $10 \mu \mathrm{m}\left(\mathrm{PM}_{10}\right)$ and total suspended particulate matter (TSP) were 
Table 1. Comparison of sources of products of combustion at McMurdo Station ${ }^{\mathrm{a}, \mathrm{b}}$ (metric tons per year).

\begin{tabular}{ccccccc}
\hline $\begin{array}{c}\text { Compound } \\
\text { discharged }\end{array}$ & $\begin{array}{c}\text { Electric } \\
\text { generation }\end{array}$ & $\begin{array}{c}\text { Water } \\
\text { distribution }\end{array}$ & $\begin{array}{c}\text { Space } \\
\text { heating }\end{array}$ & $\begin{array}{c}\text { Surface } \\
\text { vehicles }\end{array}$ & $\begin{array}{c}\text { Waste } \\
\text { incineration }\end{array}$ & Total \\
\hline $\mathrm{CO}_{2}$ & 12,341 & 6,743 & 2,023 & 2,862 & 201 & 24,170 \\
$\mathrm{H}_{2} \mathrm{O}$ & 4,114 & 2,620 & 786 & 1,124 & 188 & 8,832 \\
$\mathrm{SO}_{2}$ & 7.8 & 4.3 & 1.3 & 0.064 & 0.086 & 13.6 \\
$\mathrm{NO}_{\mathrm{x}}$ & 50.6 & 4.2 & 1.3 & 6.9 & 0.12 & 63.1 \\
$\mathrm{Part./HC}$ & 4.81 & 1.2 & 0.64 & 5.08 & 0.0068 & 11.7 \\
$\mathrm{HCl}$ & $<0.45$ & $<0.23$ & $<0.045$ & $<0.0045$ & 0.04 & $<0.77$ \\
\\
$\begin{array}{l}\text { a. Adapted from Pearson (1991). } \\
\text { b. Data based on emission factor estimates, not on actual monitoring data. }\end{array}$ \\
c. After scrubber (estimated).
\end{tabular}

Table 2. Estimated annual air pollutant emissions at MciMurdo Station (NSF 1991).

\begin{tabular}{|c|c|c|c|c|c|c|c|}
\hline \multirow[b]{2}{*}{ Source category } & \multicolumn{2}{|c|}{ Annual emission basis } & \multicolumn{5}{|c|}{$\begin{array}{l}\text { Pollutant emission rate } \\
\left.\text { (tons } \mathrm{s}^{\mathrm{a}} / \mathrm{yr}\right)\end{array}$} \\
\hline & Units & Quantity & $\mathrm{SO}_{2}$ & $\mathrm{NO}_{2}$ & PM-10 & $\mathrm{HC}$ & $\mathrm{CO}$ \\
\hline $\begin{array}{l}\text { Aircraft operations }{ }^{b} \\
\text { LC-130 and C-130 } \\
\text { C-141 } \\
\text { C-5B }\end{array}$ & $\begin{array}{l}\text { LTOs }^{c} \\
\text { LTOs } \\
\text { LTOs }\end{array}$ & $\begin{array}{c}328 \\
25 \\
5^{d}\end{array}$ & $\begin{array}{c}0.6 \\
0.004 \\
0.001\end{array}$ & $\begin{array}{l}2.9 \\
0.2 \\
0.1\end{array}$ & $\begin{array}{c}0.4 \\
0.01 \\
\text { neg. }\end{array}$ & $\begin{array}{l}8.9 \\
1.8 \\
0.2\end{array}$ & $\begin{array}{c}14.0 \\
2.2 \\
0.5\end{array}$ \\
\hline Subtotal & & & 0.7 & 3.2 & 0.4 & 11 & 17 \\
\hline $\begin{array}{l}\text { Internal combustion engines } \\
\text { Diesel (stationary and mobile) } \\
\text { Gasoline (mobile) }\end{array}$ & $\begin{array}{l}1,000 \mathrm{gal}^{\mathrm{e}} \\
1,000 \mathrm{gal}^{2}\end{array}$ & $\begin{array}{c}1,500 \\
150\end{array}$ & $\begin{array}{r}23.0 \\
0.4\end{array}$ & $\begin{array}{c}350.0 \\
7.7\end{array}$ & $\begin{array}{r}25.0 \\
0.5\end{array}$ & $\begin{array}{l}28.0 \\
15.0^{\mathrm{f}}\end{array}$ & $\begin{array}{c}77.0 \\
300.0\end{array}$ \\
\hline \multicolumn{8}{|l|}{ External combustion } \\
\hline Open burning (landfill) & \multicolumn{2}{|c|}{ Discontinued } & 0 & 0 & 0 & 0 & 0 \\
\hline \multicolumn{3}{|l|}{$\begin{array}{l}\text { Storage tanks (evaporation) } \\
\text { JP-8 } \\
\text { Gasoline }\end{array}$} & & & & $\begin{array}{l}0.2 \\
7.2\end{array}$ & \\
\hline \multicolumn{3}{|l|}{ Total McMurdo } & 29 & 374 & 28 & 63 & 398 \\
\hline \multicolumn{8}{|c|}{$\begin{array}{l}\text { a. One ton equals } 0.907 \text { metric tons. English units are used in this table because regulatory emission limits and EPA } \\
\text { emission factors are given in English units. } \\
\text { b. Sea-ice runway and skiway are approximately } 5 \mathrm{~km} \text { and } 16 \mathrm{~km} \text {, respectively, from McMurdo. } \\
\text { c. Landing take-off cycles. } \\
\text { d. Only two C-5B flights to McMurdo were reported for the } 1989-90 \text { summer season, but up to five flights per } \\
\text { season would be typical. } \\
\text { e. One gallon equals } 3.785 \text { liters. } \\
\text { f. Sum of exhaust, evaporative, and crankcase emissions. } \\
\text { g. Used emission factors from residential furnaces. }\end{array}$} \\
\hline
\end{tabular}


selected for monitoring particulate air pollution. In addition, the TSP samples were analyzed for the following seven toxic metals of interest: arsenic, beryllium, cadmium, chromium, lead, nickel, and mercury.

Utilizing historical wind data, a sampling network consisting of three locations was selected for the collection of particulate samples. The locations were selected after field reconnaissance and were based on the objectives outlined in the monitoring plan, the availability of electrical power and other operational support, and the location of major emission sources. The three sites selected were 8-Site for the predominantly upwind location, Hut Point for the predominantly downwind site, and Cent al McMurdo, near building 155, as the "worst case urban" location (see Figure 1). The original sampling and analysis plan called for the analysis of a TSP filter every 2 weeks from each of the three monitoring locations, generating a planned 24 total samples for the austral summer season. However, due to difficulties encountered in converting the highvolume sampler from the $\mathrm{PM}_{10}$ mode to the TSP mode, a reduced TSP sampling frequency was implemented, resulting in a total of seven samples for the season.

\section{METHODS}

Total suspended particulate samples were collected in accordance with EPA Reference Method for the Determination of TSP Matter (Appendix B of 40 CFR 50). A Wedding \& Associates, Inc. critical-flow high-volume sampler was used to collect particulate matter for a 24-hour period on $8 \times 10$-in. high-purity quartz fiber filters at a flowrate of approximately $1.13 \mathrm{~m}^{3} /$ minute. Filters were weighed using a Sartorius analytical balance for gravimetric determination of TSP concentration. Flow calibration was performed prior to each sample collection using the manufacturer's recommended single-point flow rate audit procedure. Using this procedure in conjunction with the critical flow device, the volumetric flow rate of the system was known to within $0.75 \%$. A mechanical timer and elapsed-time indicator on the sampler provided a record of total elapsed sampling time.

Following the gravimetric determination of the TSP concentration, each filter was placed in a glassine envelope and then placed inside a resealable plastic bag in preparation for shipment to ACZ Laboratories, Inc. in Steamboat Springs, Colorado. The samples were analyzed in the same sample delivery group. Due to the logistical challenges of shipping samples from McMurdo to the continental United States, it was anticipated that the 28-day holding time for samples undergoing mercury analysis would be exceeded; however, the recommended sample holding time of 6 months for the other six metal species was met.

The filter samples were prepared for analysis by cutting a $40-\mathrm{cm}^{2}$ strip (from a total filter area of $400 \mathrm{~cm}^{2}$ ) of filter for ultrasonic digestion (Lodge 1988). The mercury analysis, via EPA Method SW-846 7471 cold vapor atomic adsorption spectroscopy (EPA 1986) was performed directly on portions of the filter instead of the extract due to matrix interference problems with the $\mathrm{HNO}_{3} / \mathrm{HCl}$ extract. The sample extracts were then analyzed by inductively coupled plasma/mass spectrometry (ICPMS) for arsenic, beryllium, cadmium, lead, and nickel in accordance with EPA SW-846 Method 6020 (EPA 1986). Chromium required analysis by inductively coupled plasma (ICP) due to chlorine isobaric interferences with ICPMS analysis. The concentrations reported by the analytical laboratory ( $\mu \mathrm{g}$ of metal per total filter) were then divided by the total air volume sampled to obtain air concentration units of $\mu \mathrm{g} / \mathrm{m}^{3}$ or $\mathrm{ng} / \mathrm{m}^{3}$. 


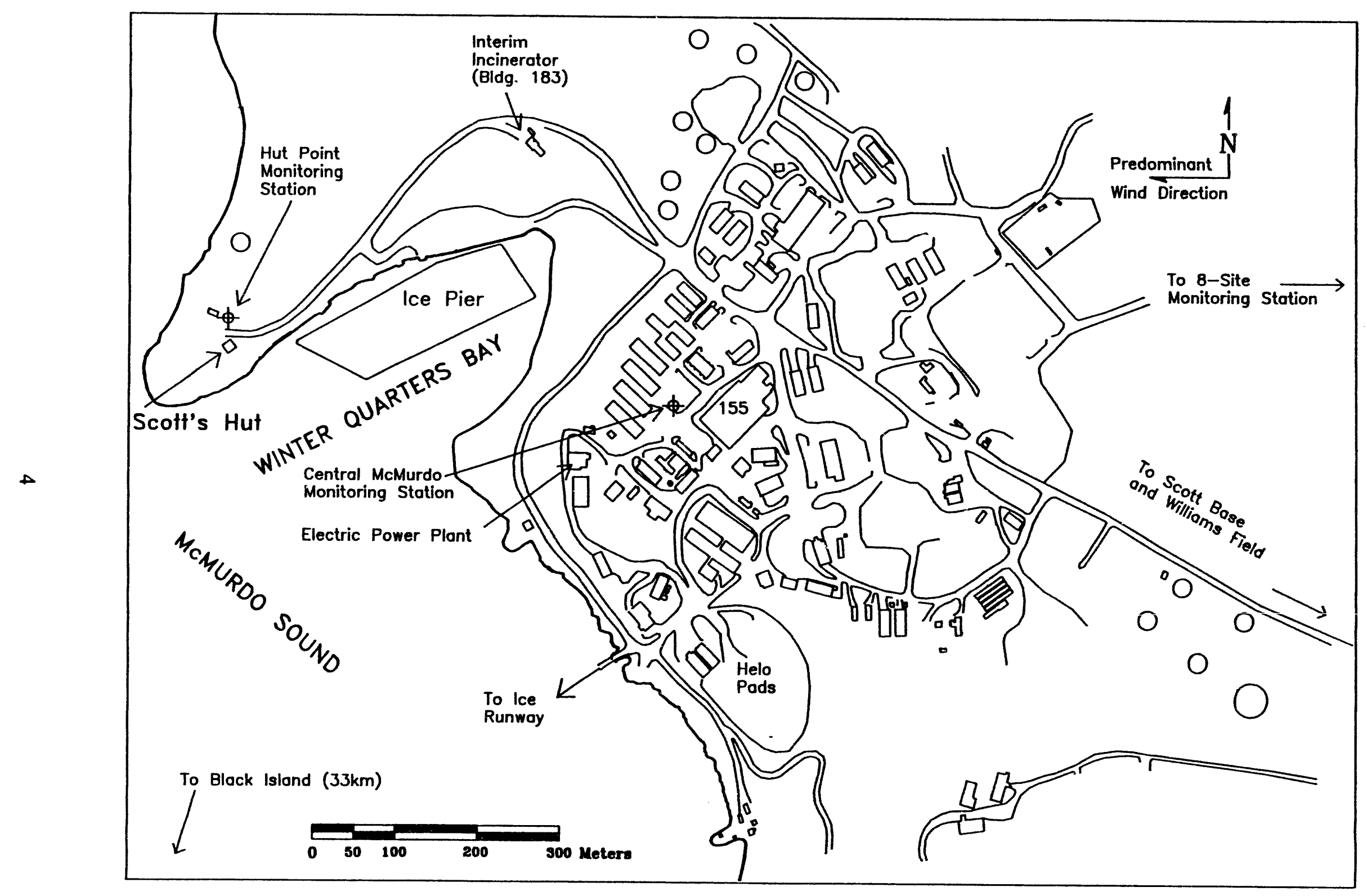

Figure 1. Map of ambient air monitoring stations at McMurdo. 


\section{RESULTS}

TSP concentrations demonstrated a correlation to sample location, with the highest particulate levels observed at the central McMurdo location, and the lowest at 8-Site (see Table 3). The TSP concentration values demonstrated greater variability between samples collected at the same location than the metals results. Note that TSP data collected after January 1, 1993, are more reliable than prior data due to improvements to the filter-weighing procedure and analytical balance environment.

In addition to the seven toxic metals of interest, the analytical results for the ICP-MS analysis included concentration data for eleven additional metal species. Although these additional data were not specifically requested in the original sampling and analysis plan, they are presented here for documentation purposes and because they help put into perspective the reported levels of the seven toxic metals of interest. Table 4 presents the results of the seven toxic metals of interest and the additional eleven metal species detected by ICP-MS analysis and reported by the analytical laboratory.

The number of toxic metals species detected and their concentrations were correlated to sampling location, with the predominantly upwind 8-Site (one sample) demonstrating the lowest number of metal species detected and the lowest concentrations, and the central McMurdo location demonstrating the highest number of metal species detected at the highest concentrations. Figures 2 through 4 provide graphical concentration profiles for all seven toxic metal species for each sample. Although the data set is limited to seven samples collected from three locations, the analytical results at a given location show remarkably little variability.

Table 3. TSP ambient air concentration data summary for McMurdo Station, austral summer 1992-1993.

\begin{tabular}{lllr}
\hline \multicolumn{1}{c}{ Date } & Filter \# & \multicolumn{1}{c}{ Location } & $\begin{array}{r}\text { Results } \\
\left(\mu \mathrm{g} / \mathrm{m}^{3}\right)\end{array}$ \\
\hline November 16, 1992 & MCM01 & Central McMurdo & 234.0 \\
November 16, 1992 & HPM01 & Hut Point & 26.5 \\
December 1, 1992 & MCM02 & Central McMurdo & 676.5 \\
December 1, 1992 & HPM02 & Hut Point & 49.7 \\
January 6, 1993 & MC07 & Central McMurdo & 138.1 \\
January 6, 1993 & HP07 & Hut Point & 42.3 \\
January 6, 1993 & TS06 & 8-Site & 6.1 \\
\hline
\end{tabular}

a. Improved weighing methods increased accuracy and reliability after January 1, 1993. 
Teble 4. Summary of metals composition of TSP filters $\left(\mathrm{ng} / \mathrm{m}^{3}\right)$.

\begin{tabular}{|c|c|c|c|c|c|c|c|}
\hline Metal & $\begin{array}{c}\text { Central McMurdo } \\
\text { MCM01 } \\
\text { November 16, } 1992\end{array}$ & $\begin{array}{c}\text { Central McMurdo } \\
\text { MCM02 } \\
\text { December 1, } 1992\end{array}$ & $\begin{array}{c}\text { Central McMurdo } \\
\text { MC07 } \\
\text { January 6, } 1993\end{array}$ & $\begin{array}{c}\text { Hut Point } \\
\text { HPM01 } \\
\text { November 16, } 1992\end{array}$ & $\begin{array}{c}\text { Hut Point } \\
\text { HPM02 } \\
\text { December 1, } 1992\end{array}$ & $\begin{array}{c}\text { Hut Point } \\
\text { HP07 } \\
\text { January 6, } 1993\end{array}$ & $\begin{array}{c}\text { 8-Site } \\
\text { TSO6 } \\
\text { January 6, } 1993\end{array}$ \\
\hline $\mathbf{A g}$ & 0.13 & 1.2 & 0.37 & 0.089 & 0.58 & 0.13 & 0.18 \\
\hline As & $\mathrm{ND}^{\mathrm{a}}(0.18)$ & ND (0.27) & ND (0.28) & ND (0.17) & ND (0.27) & ND (0.28) & ND (0.28) \\
\hline $\mathbf{B a}$ & 20 & 48 & 17 & 3.7 & 7.2 & 7.2 & 3.6 \\
\hline $\mathrm{Be}$ & ND (0.21) & 0.63 & ND (0.17) & ND (0.035) & ND (0.11) & ND (0.055) & ND (0.055) \\
\hline Cd & 0.39 & 2.0 & $0.33 \mathrm{~B}^{\mathrm{b}}$ & ND (0.069) & $0.32 \mathrm{~B}$ & $0.11 \mathrm{~B}$ & ND (0.11) \\
\hline Co & 2.1 & 5.5 & 1.5 & 0.17 & 0.54 & 0.36 & 0.058 \\
\hline $\mathrm{Cr}$ & 6.4 & 14 & 3.7 & ND (1.7) & ND (2.7) & ND (2.7) & ND (2.8) \\
\hline $\mathrm{Cu}$ & 120 & 160 & 230 & 170 & 30 & 170 & 120 \\
\hline $\mathrm{Hg}$ & $0.18 \mathrm{JHT}^{\mathrm{c}}$ & $0.22 \mathrm{JHT}$ & $0.28 \mathrm{JHT}$ & $0.17 \mathrm{JHT}$ & $0.16 \mathrm{JHT}$ & $0.16 \mathrm{JHT}$ & $0.22 \mathrm{JHT}$ \\
\hline $\mathbf{M b}$ & 0.76 & 2.2 & 0.88 & 0.25 & 0.66 & 0.61 & 0.41 \\
\hline Mn & 84 & 200 & 68 & 10 & 23 & 18 & 2.9 \\
\hline $\mathbf{N i}$ & $6.1 \mathrm{~B}$ & $14 \mathrm{~B}$ & $5.3 \mathrm{~B}$ & $1.0 \mathrm{~B}$ & $2.9 \mathrm{~B}$ & $3.0 \mathrm{~B}$ & $1.1 \mathrm{~B}$ \\
\hline $\mathrm{Pb}$ & $20 \mathrm{~J}^{\mathrm{d}}$ & $38 \mathrm{~J}$ & $33 \mathrm{~J}$ & $4.2 \mathrm{~J}$ & $4.6 \mathrm{~J}$ & $5.8 \mathrm{~J}$ & $1.4 \mathrm{~J}$ \\
\hline $\mathbf{S b}$ & 0.13 & 1.5 & 0.15 & ND $(<0.0)$ & 0.33 & 0.047 & 0.025 \\
\hline $\mathrm{Ti}$ & 850 & 2,100 & 640 & 88 & 220 & 170 & 24 \\
\hline $\mathbf{U}$ & 0.25 & 0.60 & 0.22 & 0.023 & 0.058 & 0.056 & 0.041 \\
\hline $\mathbf{v}$ & 18 & 34 & 9.9 & 0.37 & 1.3 & 0.47 & ND $(<0.0)$ \\
\hline $\mathrm{Zn}$ & 21 & 64 & 17 & 5.4 & 14 & 12 & 4.7 \\
\hline
\end{tabular}



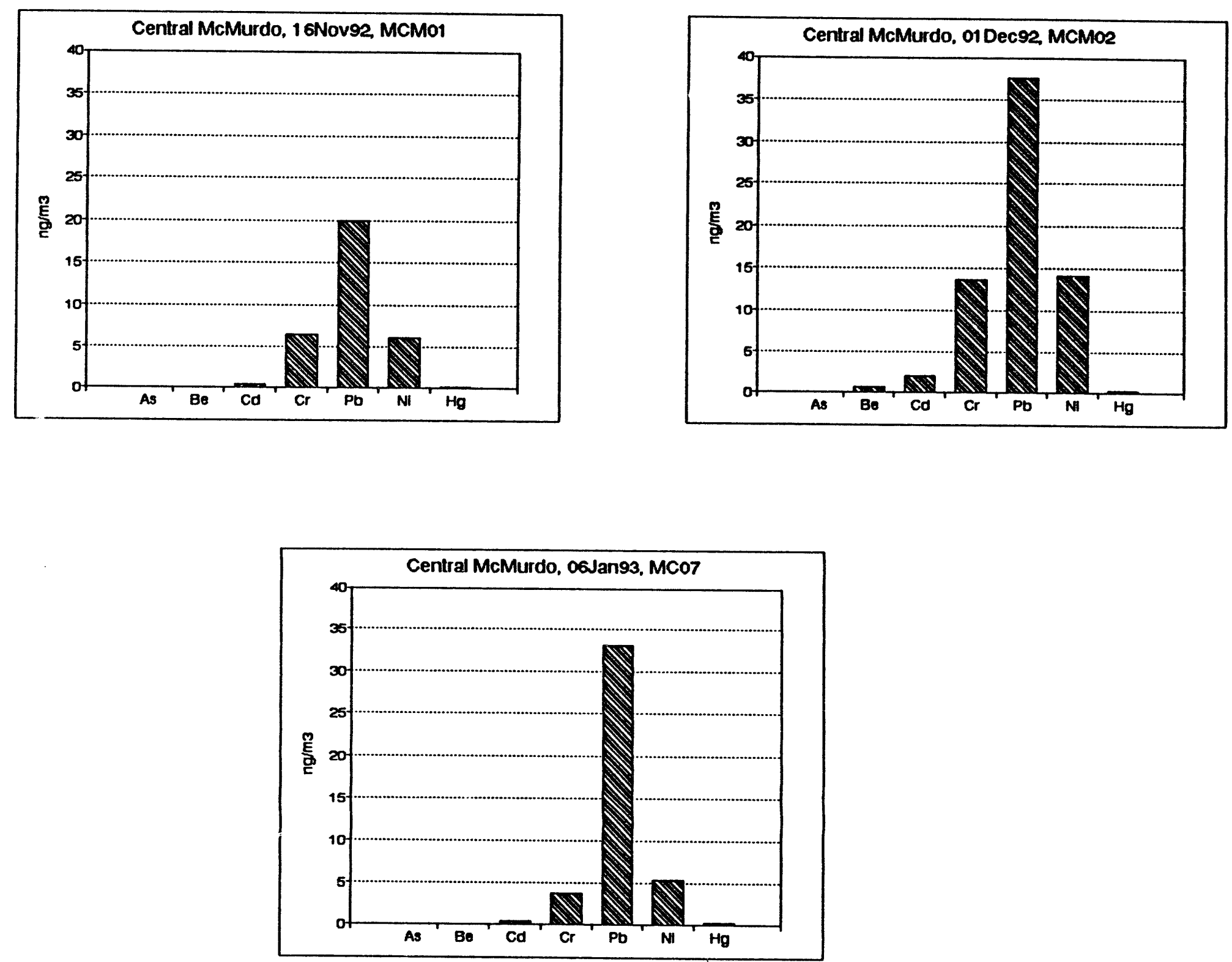

Figure 2. TSP toxic metals concertration at Central McMurdo. 

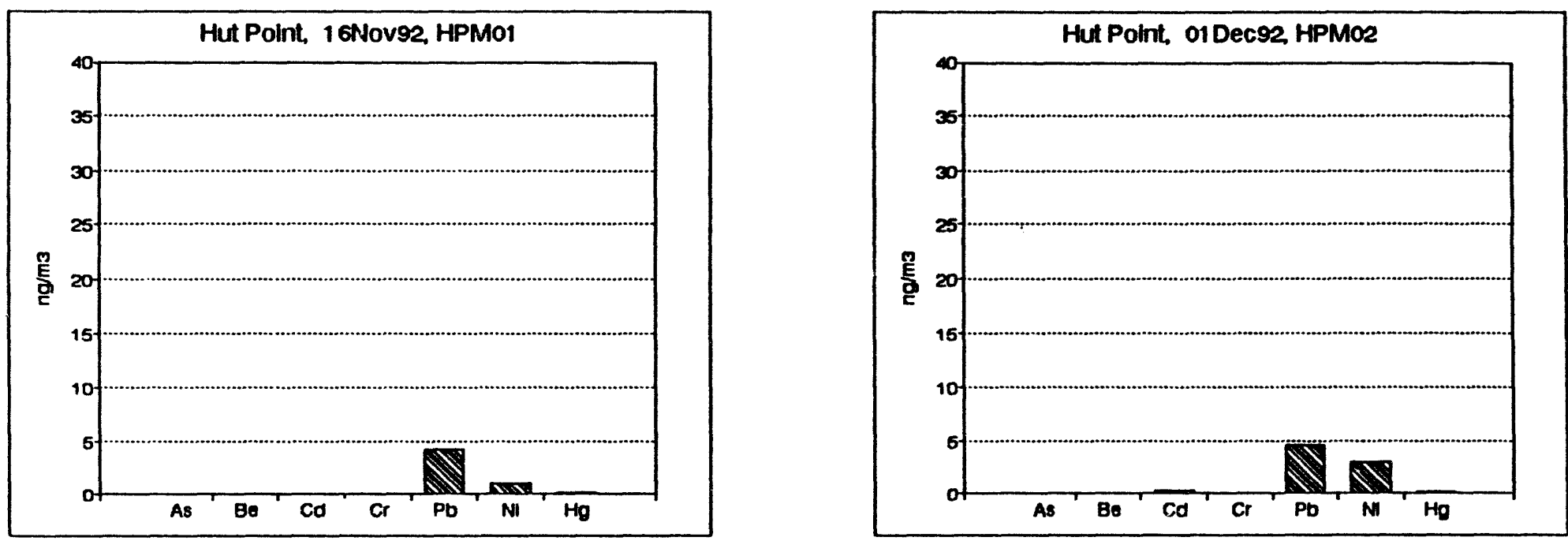

$\infty$

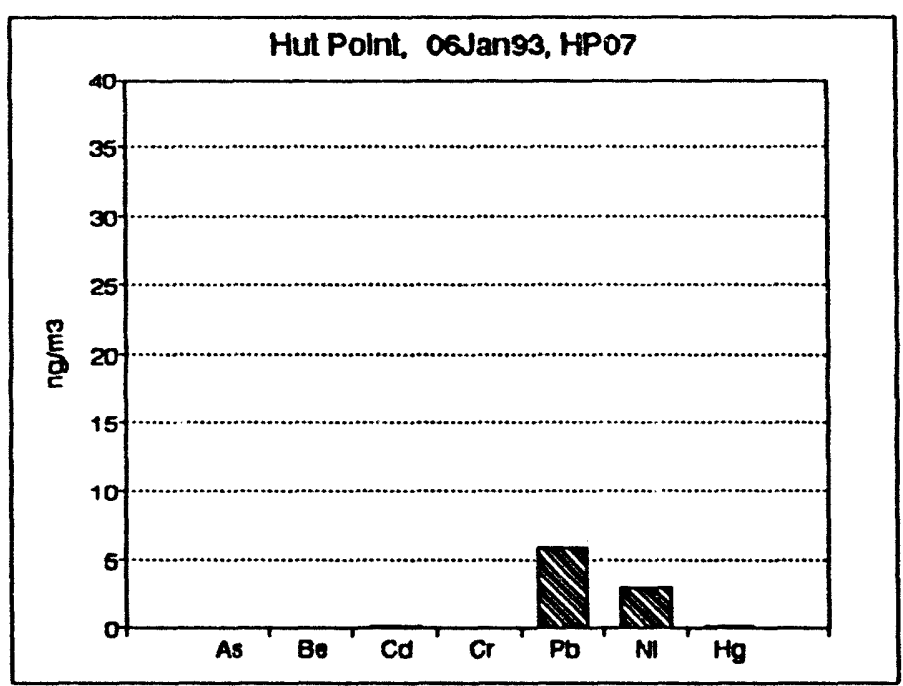

Figure 3. TSP toxic metals concentration at Hut Point. 


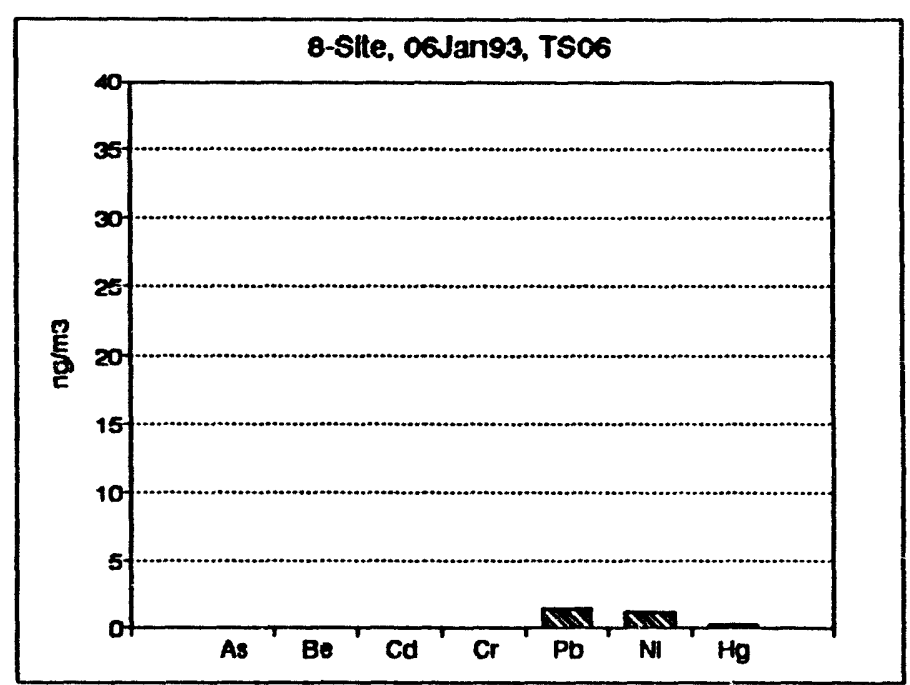

Figure 4. TSP toxic metals concentration at 8-Site. 
These data indicate that McMurdo operations appear to have a measurable impact on the qualitative metals composition of suspended particulate matter in the ambient air. The toxic metal air concentration data alone further support the theory that base operations should measureably impact the quantitative airborne metals composition; however, an evaluation of the metal-to-particulate ratio of these samples does not reveal the expected "enrichment" of the Central McMurdo and Hut Point particulate samples as compared to the upwind 8-Site sample. This ratio displays just the opposite effect (see Figures 5 through 7). This contradiction may be explained by any one or a combination of the following:

- The Central McMurdo and Hut Point TSP samples had filter loadings up to two orders of magnitude larger than the 8-Site, with much of that loading suspected of being caused by wind-blown resuspension and deposition of larger particles blown onto the filter, therby creating a significant disparity in the particle size distribution of the collected particulate matter.

- The laboratory detection limits were not sufficiently low enough, particularly for the low mass of matter collected on the 8-Site sample; conversely, the sample time was too short on this sample to permit collection of sufficient mass for the selected analytcal $\operatorname{method}(\mathbf{s})$.

- The lack of a filter blank analysis and analytical laboratory quality control issues diminish certain aspects of the data reliability.

The reported levels of all seven metals at all three locations are well below U.S. National Ambient Air Quality Standards (NAAQSs) and American Conference of Governmental Industrial Hygienists threshold limit values for chemical substances.

Arsenic was not detected in any sample. Beryllium was not detected in any samples except for a single sample collected from central McMurdo (MCM02) that indicated a trace beryllium concentration of $0.63 \mathrm{ng} / \mathrm{m}^{3}$. Cadmium was measured in two of the three Hut Point samples at 0.11 and $0.32 \mathrm{ng} / \mathrm{m}^{3}$, respectively, and in all three central McMurdo samples at levels ranging from 0.33 to $2.0 \mathrm{ng} / \mathrm{m}^{3}$. Cadmium was not detected at the upwind 8-Site location. Chromium was detected only at the central McMurdo location at levels ranging from 3.7 to $14 \mathrm{ng} / \mathrm{m}^{3}$. Nickel was detected in all samples at levels ranging from 1 to $14 \mathrm{ng} / \mathrm{m}^{3}$, with central McMurdo exhibiting the highest values. Mercury was detected in all samples at estimated levels ranging from 0.16 to $0.28 \mathrm{ng} / \mathrm{m}^{3}$; however, only estimated quantification was possible due to quality control problems with this analysis at the analytical laboratory, and the exceedance of recommended sample hoding time. The highest mercury values reported were at central McMurdo.

Lead is the only metal with an established NAAQS. Lead was detected in all seven air samples, and was the most prevalent of the seven toxic metals of interest in all samples. Lead concentrations ranged from $1.4 \mathrm{ng} / \mathrm{m}^{3}$ at $8-S i t e$ to a maximum value of $38 \mathrm{ng} / \mathrm{m}^{3}$ at central McMurdo, well below the NAAQS of $1,500 \mathrm{ng} / \mathrm{m}^{3}$ maximum arithmetic mean averaged over a calendar quarter; however, only estimated quantification was possible due to quality control problems with this analysis at the analytical laboratory. One likely explanation of the relative abundance of lead compared to the other six toxic metals of interest is the past use of leaded fuel at McMurdo and localized surface deposition of lead from vehicle and aircraft emissions. 


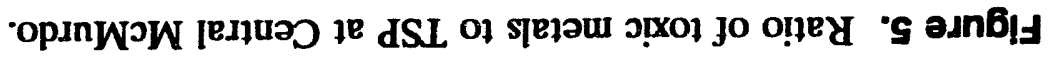
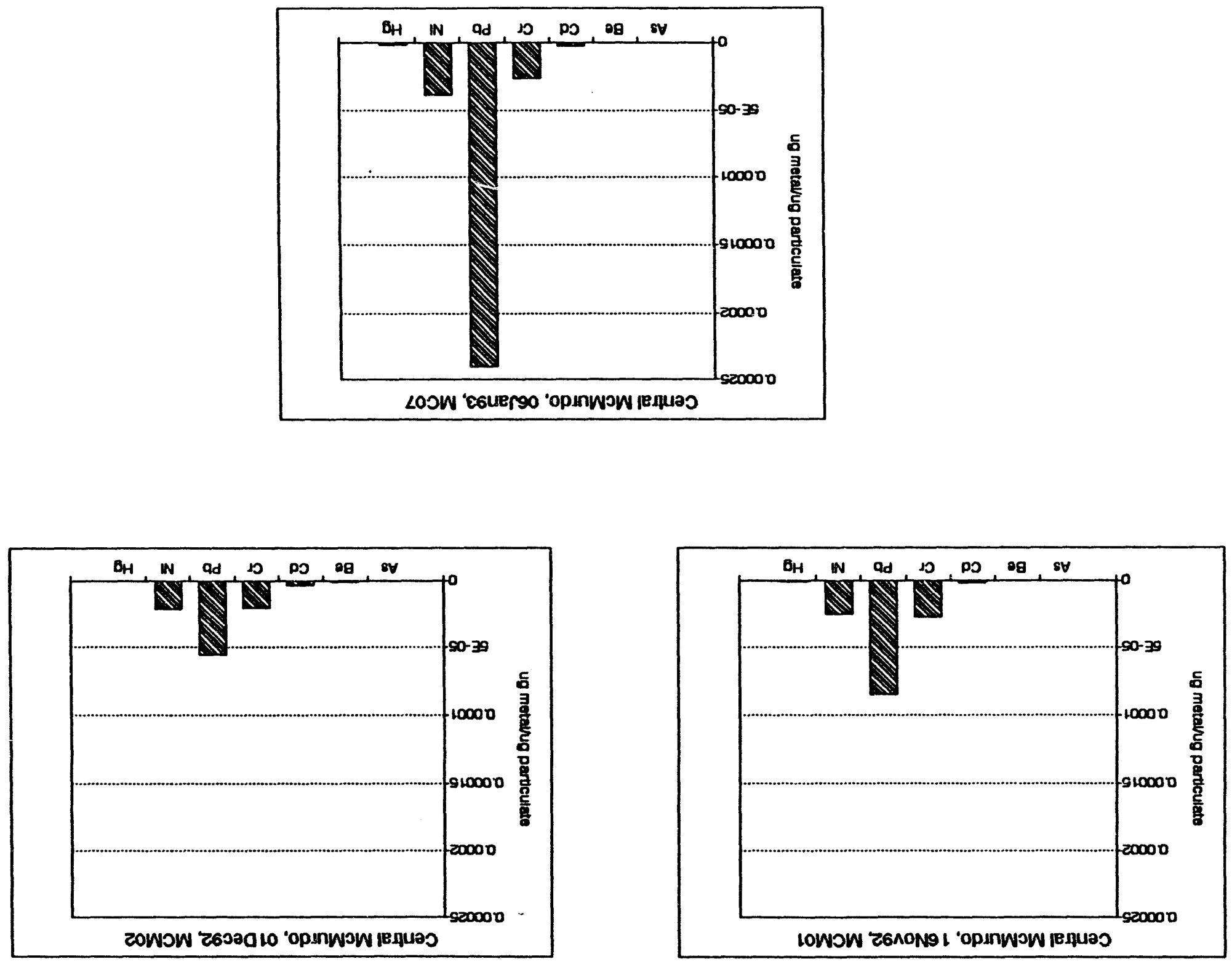

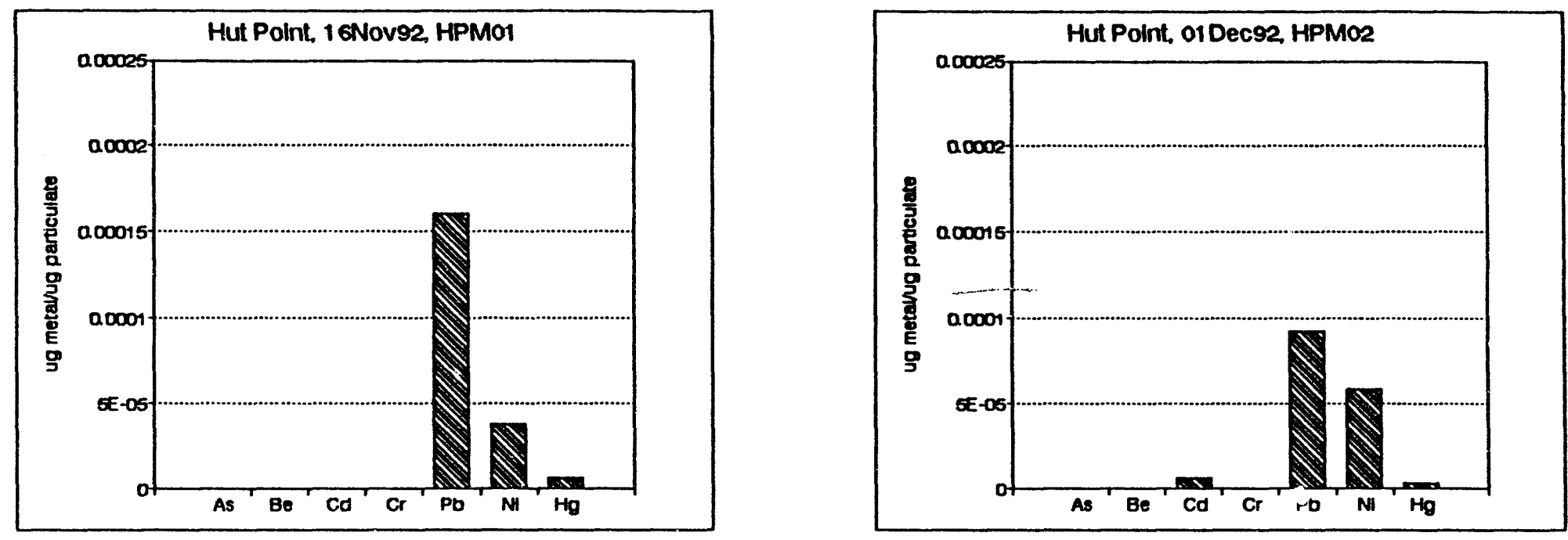

$\vec{N}$

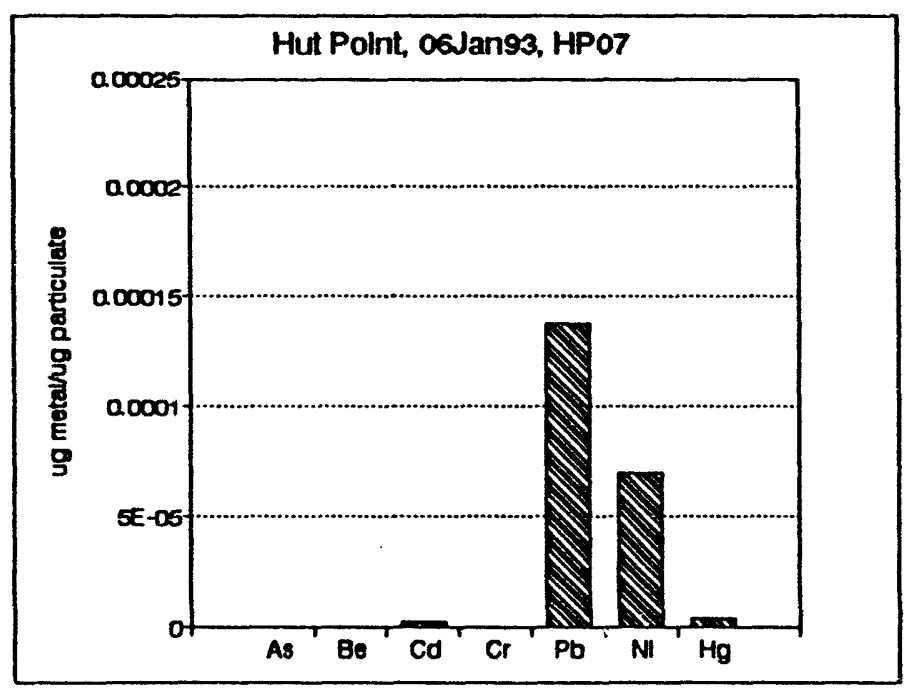

Figure 6. Ratio of toxic metals to TSP at Hut Point. 


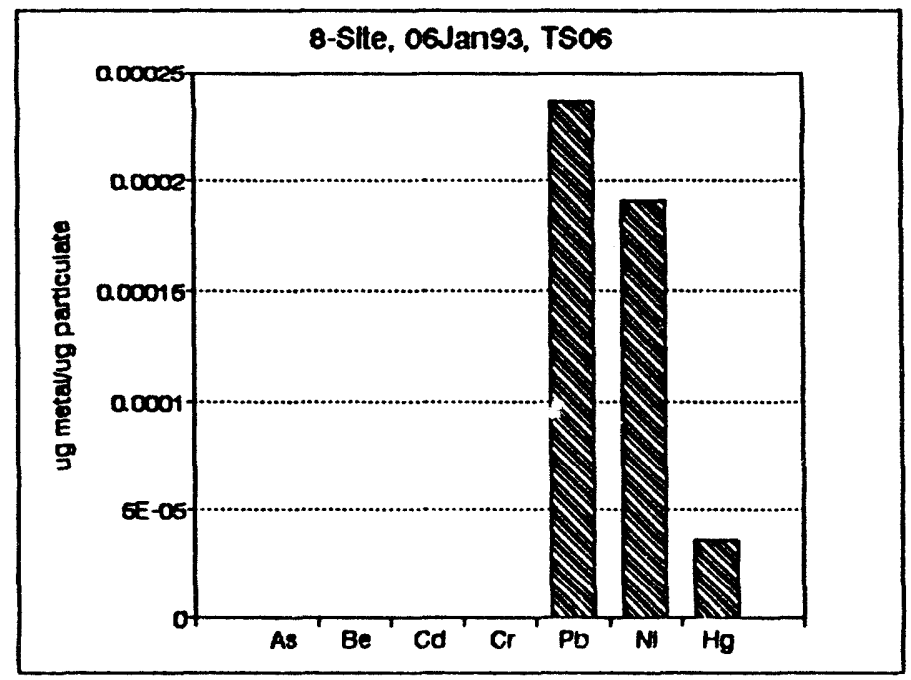

Figure 7. Ratio of toxic metals to TSP at 8-Site. 
Although leaded fuel use at McMurdo ceased sometime prior to 1990, resuspension of previously deposited lead particles by wind and vehicle traffic are a potential secondary source for this contaminant. For comparative purposes, the average central McMurdo lead concentration of $30 \mathrm{ng} / \mathrm{m}^{3}$ is similar to quarterly maximum lead levels measured in 1991 in ambient air in the U.S. cities of Portland, Maine; Atlantic City, New Jersey; and Colorado Springs, Colorado (EPA 1992).

Validation of the data for the seven toxic metals of interest indicated these data limitations:

- Mercury analyses for all samples were performed outside of the 28-day holding time. Only positive results (estimated) were reported for this analyte, and these results are flagged in Table 4 with "JHT."

- One matrix spike recovery for lead slightly exceeded the $125 \%$ upper limit $(127 \%)$; therefore, positive lead results are qualified in Table 4 with a "J" flag.

- Positive values greater than the instrument detection limit were reported for beryllium, lead, and nickel in the laboratory method blanks, affecting all samples. However, positive sample results less than five times the positive maximum blank contaminant concentration was considered as not detected (ND), and impacted only the beryllium results of three samples.

The other eleven metal species concentrations determined by ICP-MS and reported in Table 4 have not been validated, but are included for informational purposes. The submission of a filter blank (clean filter) for analyses to assess the potential contribution of the filter media to the reported metals concentration was inadvertently omitted. It is unlikely that the filters introduced any significant error based on prior evaluation of trace element content of aerosol filters that included the Whatman QM-A quartz fiber filters used for this study (Berg and Royset 1993).

Graphical concentration profiles of all 18 metal species detected for each sample are presented in Figures 8 through 10. It is interesting to note the apparent relative abundance of copper and titanium in all samples. Titanium ranged from 24 to $2,100 \mathrm{ng} / \mathrm{m}^{3}$, and copper ranged from 30 to $230 \mathrm{ng} / \mathrm{m}^{3}$. It is hypothesized that this may be attributed to the relative abundance of these elements in the native volcanic soils of the McMurdo locale; however, no previous data specifically reporting the metals composition of undisturbed native soils in the McMurdo area are known to exist. Metals in surface soil data from previous characterization studies of potentially contaminated sites at McMurdo were reviewed for possible comparison; however, none of these studies collected background or control samples, and none were analyzed for titanium (ANL 1992; AECOM 1992). Studies of nearby Mount Erebus magma element abundances, volatile element emissions, and volcanic bomb composition (Dunbar and Kyle 1990; Kyle et al. 1990) confirm the presence of titanium and copper species in relatively large concentrations, but it is difficult to relate data in these studies to the metals composition of the McMurdo area soils.

Future metals analysis of $\mathrm{PM}_{10}$ air-filter samples collected during the 1993-1994 austral summer are expected to provide a larger data set for an improved evaluation of the impact of McMurdo operations on the metals composition of particulate matter in the local ambient air. 
Central McMurdo, 16Nov92, MCM01

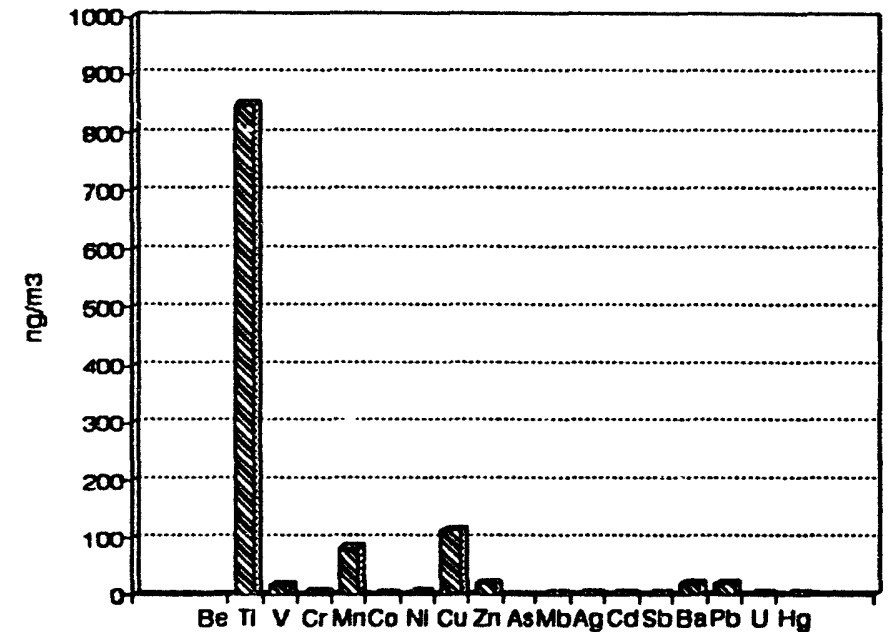

Central McMurdo, 01Dec92, MCM02

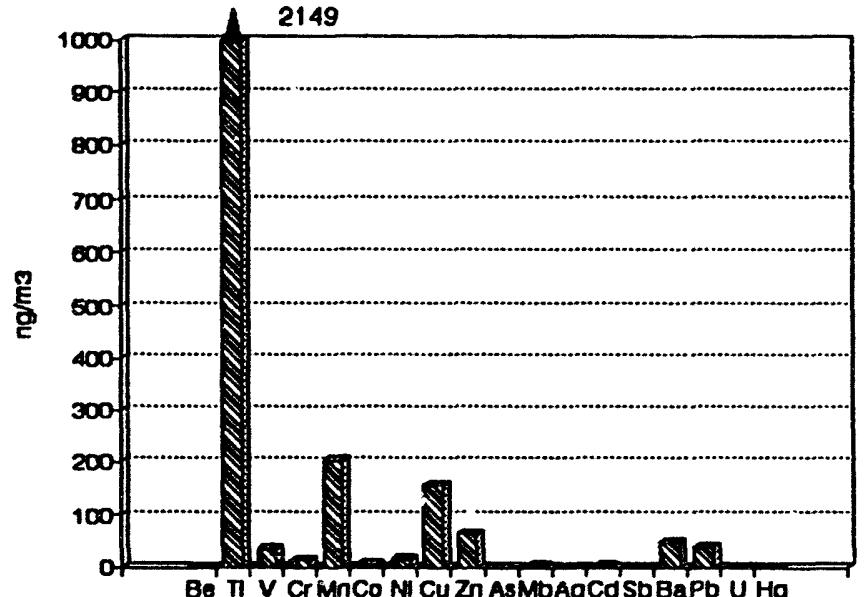

Be $n$ V Cr MnCo NI CuZ ZAsMbAgCósDBaPb U $\mathrm{Hg}$

Central McMurdo, 06JAN93, MC07

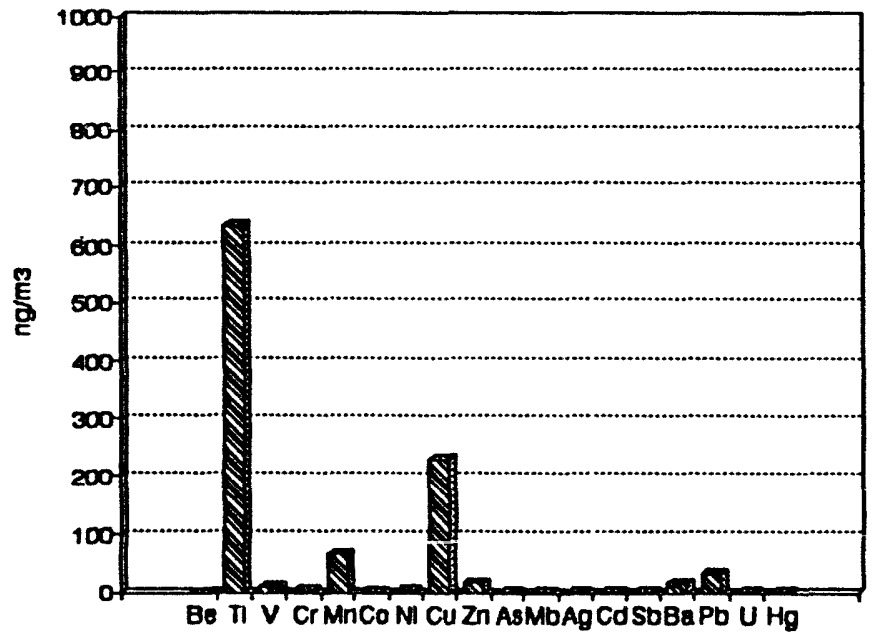

Figure 8. Total TSP metals at Central McMurdo. 
Hut Point, 16Nov92, HPM01

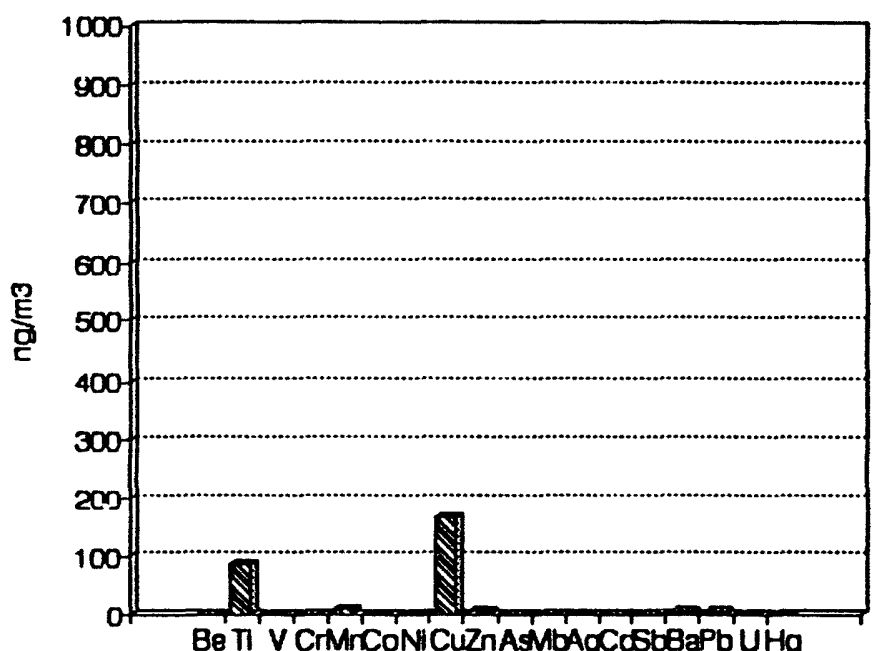

Hut Point, 01Dec92, HPM02

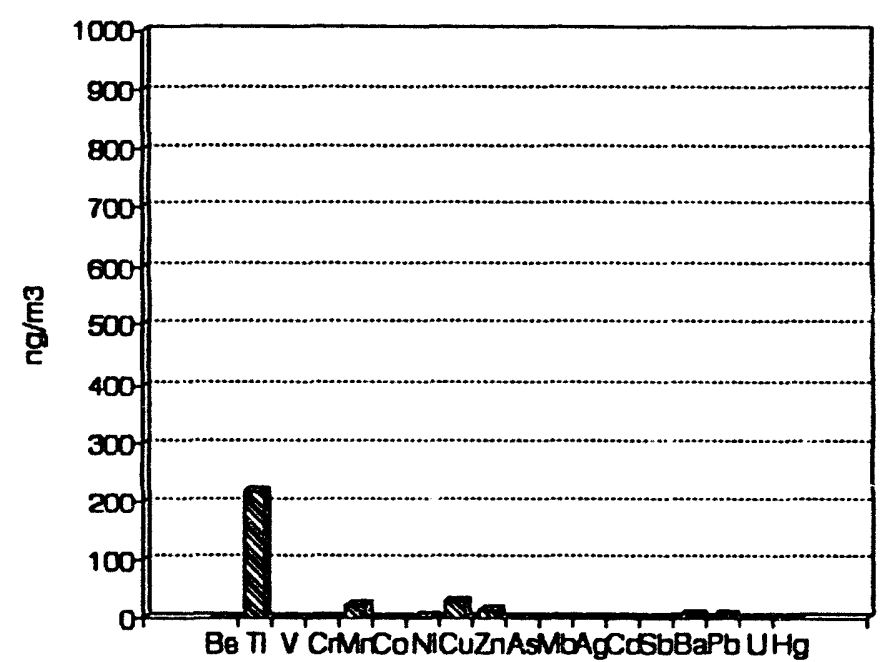

Hut Point, 06Jan92, HP07

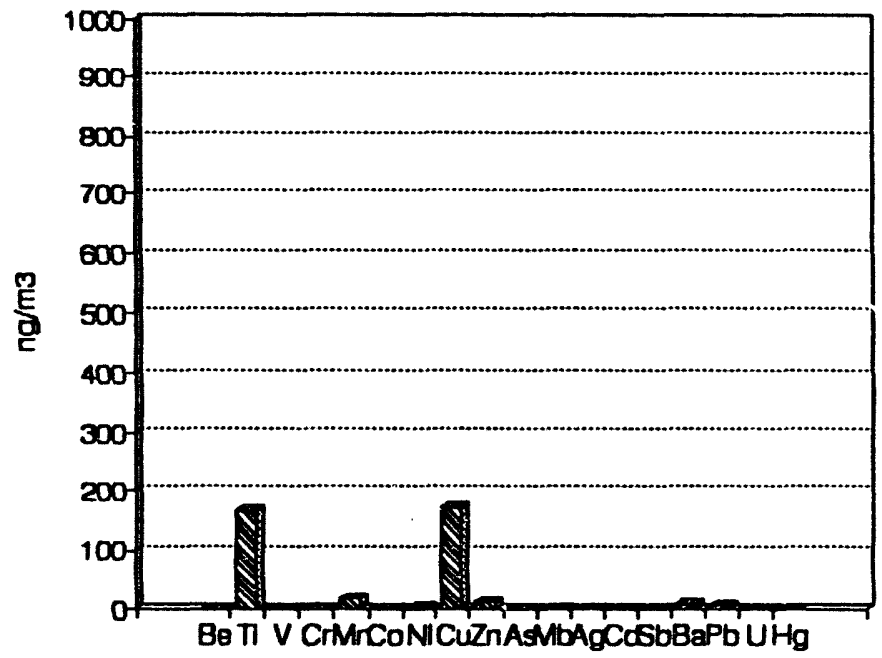

Figure 9. Total TSP metals at Hut Point. 
8-Site, 06/an93, TS06

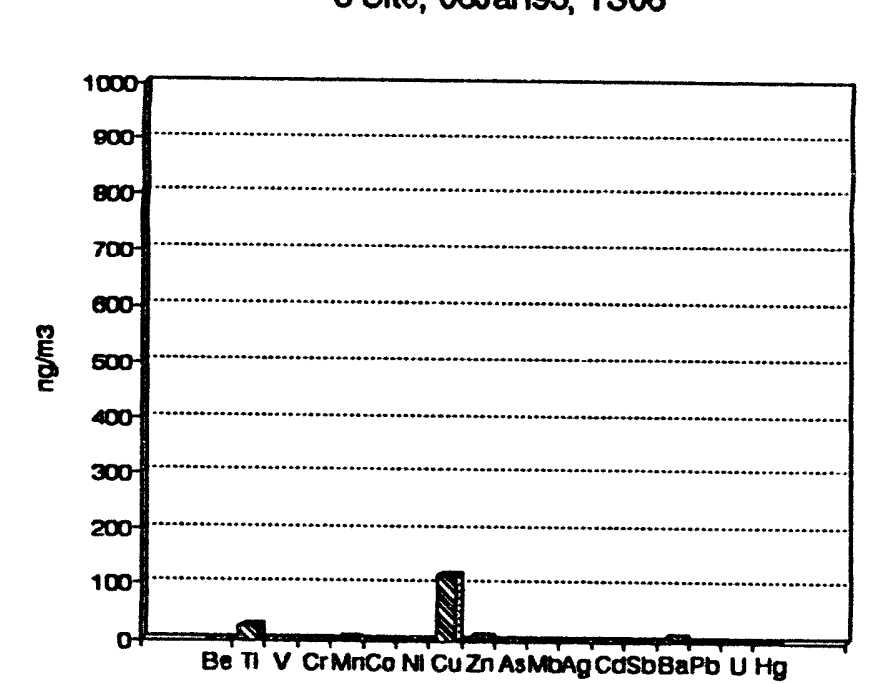

Figure 10. Total TSP metals at 8-Site. 


\section{REFERENCES}

AECOM Technology Corporation, 1992, Final Fortress Rocks Landfill Remediation Report for McMurdo Station, Antarctica, prepared for Antarctic Support Associates by AECOM, Fairfax, VA 22031, July 1992.

ANL (Argonne National Laboratory), 1992, Final Report Preliminary Site Investigation at McMurdo Station, Ross Island, Antarctica, by Environmental Assessment and Information Sciences Division and Environmental Research Division, Argonne National Laboratory, Argonne, IL 60436 for the National Science Foundation, July 1992.

Berg, T. and O. Royset, 1993, "Blank Values of Trace Elements in Aerosol Filters Determined by ICP-MS," Atmospheric Environment, 27A, 15, pp. 2,435-2,439.

CFR (Code of Federal Regulations) 40 Part 58, Appendix D, "Network Design for State and Local Air Monitoring Stations (SLAMS) and National Air Monitoring Stations (NAMS)," July 1989.

CFR 40 Part 50, Appendix B, "Reference Method for the Determination of Suspended Particulate Matter in the Atmosphere (High-Volume Method)," and Appendix J, "Reference Method for the Determination of Particulate Matter as $\mathrm{PM}_{10}$ in the Atmosphere," Office of the Federal Register, July 1991.

Dunbar, N. W. and P. R. Kyle, 1990, "Volatile Contents of Melt Inclusions in Anorthoclase Phenocrysts from Mt. Erebus: Implications for Magmatic Crystallization," Antarctic Journal, 1990 Review, $X X V$, 5, pp. 7-9.

EPA (U.S. Environmental Protection Agency), 1977, Quality Assurance Handbook for Air Pollution Measurement Systems, Volume II - Ambient Air Specific Methods, EPA-600/4-77027a, Research Triangle Park, NC, May 1977.

EPA, 1986, Test Methods for Evaluating Solid Waste, SW-846 Third Edition, EPA Office of Solid Waste and Emergency Response, November 1986 including Update I to the Third Edition, July 1993.

EPA, 1992, National Air Quality Trends and Emissions Trends Report, 1991, 450-R-92-001, EPA Office of Air Quality Planning and Standards, Research Triangle Park, NC, October 1992.

Kyle, P. R., K. Meeder, W. C. McKintosh, N. W. Dunbar, B. Andres, and D. Caldwell, 1990, "Volatile Emissions from Mt. Erebus," Antarctic Joumal 1990 Review, XXV, 5, pp. 9-11.

Lodge, J. P. (ed.), 1988, Methods of Air Sampling and Analysis, Third edition, Lewis Publishers, Inc., 121 South Main St., Chelsea, MI 48118, pp. 365-369. 
Lugar, R. M., 1992, FY-1993 Ambient Air Monitoring Plan for McMurdo Station, Antarctica, prepared for the National Science Foundation Division of Polar Programs, EG\&G Idaho, Inc., Idaho Falls, ID 83415-1406, September 1992.

NSF (National Science Foundation), 1989, Implementation of the National Science Foundation's Strategy for Compliance with Environmental Law in Antarctica, Washington, D.C., 19 pp., 1989.

NSF, 1991, Supplemental Environmental Impact Statement for the United States Antarctic Program, National Science Foundation, Washington, D.C., October 1991.

Pearson, C. V., 1991, Technology Assessment: Evaluation and Design of a High Temperature Incinerator for Treatment of Solid Wastes at McMurdo Station, Ross Island, Antarctica, Part II: Reference System Description for the Interim Incinerator Facility, Argonne National Laboratory, Argonne, IL, June 1991. 

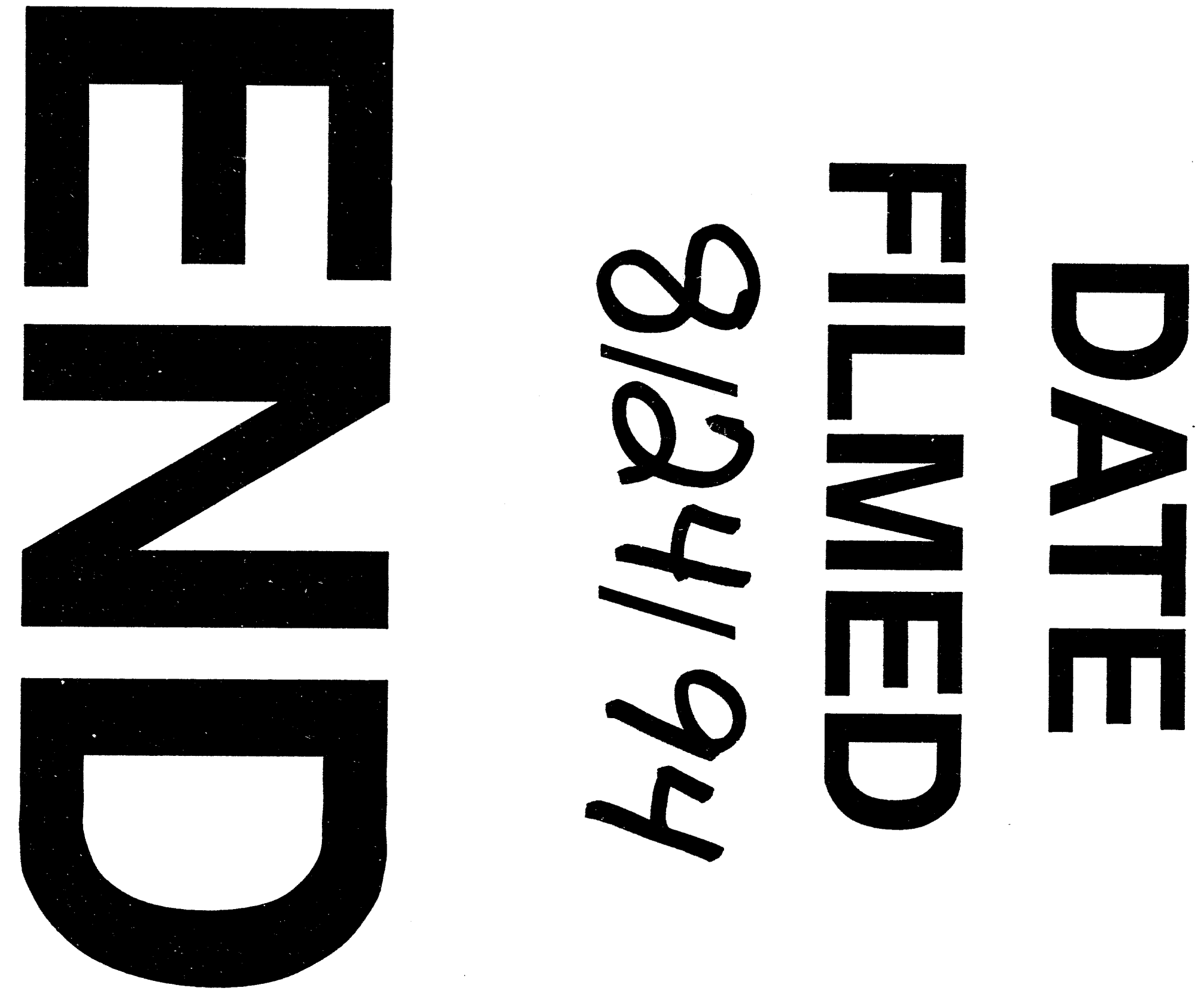
